\title{
Analysis of 16S rDNA Sequences from Citrus Huanglongbing Bacteria Reveal a Different “Ca. Liberibacter" Strain Associated with Citrus Disease in São Paulo
}

\author{
H. D. Coletta-Filho, M. A. Takita, M. L. P. N. Targon, and M. A. Machado, Centro APTA Citros Sylvio Moreira, \\ Instituto Agronômico, CEP 13490-970, CP04, Cordeirópolis SP, Brazil
}

\begin{abstract}
Coletta-Filho, H. D., Takita, M. A., Targon, M. L. P. N., and Machado, M. A. 2005. Analysis of 16S rDNA sequences from citrus huanglongbing bacteria reveal a different " $\mathrm{Ca}$. Liberibacter" strain associated with citrus disease in São Paulo. Plant Dis. 89:848-852.

Citrus huanglongbing (HLB, ex greening) is one of the most serious and destructive citrus diseases in the world. It is caused by a phloem-limited and nonculturable bacterium, "Candidatus Liberibacter". The disease occurs in some Asian and African countries and recently has been reported in the state of São Paulo, Brazil. Analysis of the 16S ribosomal (r)DNA of the HLB bacteria from orchards in São Paulo revealed the presence of two distinct strains of " $\mathrm{Ca}$. Liberibacter". One of them, named LSg1 (Liberibacter sequence group 1), was $100 \%$ identical to strains from Japan (GenBank accessions AB038369 and AB008366), the Asian forms of the bacteria. The other, $\mathrm{LSg} 2$, is genetically distant from the Asian (96.1 to $96.3 \%$ identity) and African (95.8 to $96.1 \%$ identity) strains. Comparison of the $16 \mathrm{~S}$ rDNA sequences from the $\mathrm{LSg} 2$ and the Asian strain revealed the presence of INDELs and point mutations. Specific primers designed for this Brazilian Liberibacter strain revealed that it is more widely distributed throughout the São Paulo orchards compared with the LSg1 strain. The HLB symptoms caused by both strains are almost identical and, interestingly, both strains were found in the same sample, revealing mixed infection in a citrus plant.
\end{abstract}

Additional keywords: PCR, sweet orange

Huanglongbing (HLB), ex citrus greening, is one of the most serious diseases that occur in citrus. The symptoms include leaf mottling, yellowish shoots, and, frequently, small and lopsided fruit. It is caused by a phloem-limited, gram-negative, nonculturable bacterium designated "Candidatus Liberibacter", a member of the alphasubdivision of the phylum Proteobacteria (11). Two forms of HLB disease are known, African and Asian (1). The African form is caused by a heat-sensitive and Trioza erytreae-vectored bacterium designated " $\mathrm{Ca}$. L. africanus", whereas the Asian form is caused by a heat-tolerant and Diaphorina citri-vectored bacteria named " $C a$. L. asiaticus". Both insect vectors can naturally transmit their respective form of bacteria, which infect all Citrus spp. and cultivars. The disease causes severe losses in the production of sweet orange (Citrus sinensis), mandarin (C. re-

Corresponding author: H. D. Coletta-Filho E-mail: helvecio@centrodecitricultura.br

The nucleotide sequence data reported in this article appear in the GenBank nucleotide sequence databases with the accessions number AY 919311 and AY 919312.

Accepted for publication 13 April 2005.

DOI: 10.1094/PD-89-0848

(C) 2005 The American Phytopathological Society ticulata), lemon ( $C$. limon), grapefruit ( $C$. paradisi), and other economically important citrus species (6). In addition to some Asian countries, where the disease and the vector are endemic, the psylla $D$. citri also is present in the states of São Paulo in Brazil and Florida in the United States, the main orange juice production areas in the world $(5,7)$.

In mid-2004, the Asian form of HLBbacteria ("Ca. L. asiaticus") was detected by molecular means and characterized from HLB-symptomatic citrus plants in São Paulo (Brazil) (2). More recently, Teixeira et al. (19) detected a different liberibacter isolate associated with HLBdiseased plants from São Paulo and designated it as " $\mathrm{Ca}$. L. americanus", which is predominant in the state of São Paulo, being detected in $98 \%$ of the samples analyzed compared with $2 \%$ of sequences from $\mathrm{Ca}$. L. asiaticus. Due to the abundance of the endemic D. citri in citrus orchards in the state of São Paulo and the large areas occupied by this culture, the HLB disease has scared citrus researchers and growers in Brazil. An outbreak of an infectious disease often results from an exposure to a common source of a clonally related pathogen. However, in a clonally related pathogen, there is sufficient diversity at the species level that organisms isolated from different hosts and different geographic regions may be differentiated (16). In epidemiology, the knowledge of genetic variations in the pathogen is important for determining the source of infection and identification of genetic variants that can be associated with the pathogenicity.

Comparison of the $16 \mathrm{~S}$ ribosomal DNA (16S rDNA) sequences with other microorganisms has increased the knowledge about the biology, diagnosis, and epidemiology of noncultivable or unknown bacteria (14). The $16 \mathrm{~S}$ rDNA sequences among Asian isolates of " $\mathrm{Ca}$. Liberibacter" were quite similar, with 98.8 to $100 \%$ identity; whereas, among African isolates, the identity was $97.5 \%$ (18). The American isolate shared 93.7 and $93.9 \%$ identity with the African and Asian forms, respectively (19). The " $C a$. L. africanus subsp. capensis", detected by polymerase chain reaction (PCR) in an ornamental rutaceous plant (Calodendrum capense), differs from the citrus liberibacters in relation to the $16 \mathrm{~S}$ rDNA, intergenic 16S/23S rDNA and also serology (4).

The objectives of this study were to detect and compare the HLB bacteria in citrus trees with HLB symptoms in the state of São Paulo, Brazil. For this purpose, the $16 \mathrm{~S}$ rDNA of HLB liberibacters was amplified, sequenced, compared with Asian and African forms of bacteria, and used to develop primers for specific diagnostic assays. This work confirmed the existence of a third form of HLB liberibacter, previously named " $\mathrm{Ca}$. L. americanus", which is the most prevalent form of this bacterium in Brazil.

\section{MATERIALS AND METHODS}

Plant materials. Leaves and shoots of citrus plants showing HLB symptoms were collected in different geographic regions of the state of São Paulo, Brazil (Fig. 1). Healthy citrus plants obtained through shoot-tip grafting were used as negative controls. Total DNA from African liberibacter was used as a positive control (kindly provided by Dr. Michael Luttig, ARC-Institute for Tropical and Subtropical Crops, Nelspruit, South Africa).

DNA extraction. DNA was extracted from leaf midribs and bark of the diseased and healthy plants by the elution procedure as described by Jagoueix et al. (12). Briefly, $300 \mathrm{mg}$ of plant tissue was minced with a razor blade and put in a 1.5-ml tube containing $1 \mathrm{ml}$ of Tris-EDTA buffer (50 $\mathrm{mM}$ Tris-HCl, $\mathrm{pH}$ 8.0, 5 mM EDTA, $1 \%$ sodium dodecyl sulfate) to which $0.15 \mathrm{mg}$ 
of proteinase $\mathrm{K}$ was added. The tube was incubated at $65^{\circ} \mathrm{C}$ for $2 \mathrm{~h}$, after which the suspension was centrifuged for $8 \mathrm{~min}$ at $12,000 \mathrm{rpm}$ and $600 \mu \mathrm{l}$ of the supernatant was removed to a new tube. The DNA was further purified using the Wizard Genomic purification kit (Promega Corp., Madison, WI) according to the manufacturer. Of the total DNA obtained, $5 \mu \mathrm{l}$ were used for PCR assays.

PCR amplification. The reactions were performed in $25-\mu$ l reaction mixtures (10 mM Tris- $\mathrm{HCl}, \mathrm{pH} 8.3,50 \mathrm{mM} \mathrm{KCl}, 1.5 \mathrm{mM}$ $\mathrm{MgCl}_{2}$ ), $2 \mathrm{mM}$ each dNTP, 1 unit of Taq DNA polymerase (Invitrogen), $5 \mu$ of DNA extract, and $20 \mathrm{ng}$ of each primer. The liberibacter $16 \mathrm{~S}$ rDNA was amplified specifically with the OI1 and OI2c primers (Table $1 ; 12$ ). The PCR was carried out in a PTC 100 thermocycler (MJ Research, Watertown, MA) with the following setup: a first step at $94^{\circ} \mathrm{C}$ for 3 min followed by 36 cycles of a denaturation step at $94^{\circ} \mathrm{C}$ for 30 $\mathrm{s}$; an annealing step with temperature varying from 55 to $60^{\circ} \mathrm{C}$, depending on the primers (Table 1), for $45 \mathrm{~s}$; extension at $72^{\circ} \mathrm{C}$ for $45 \mathrm{~s}$; and a final extension of 10 $\min$ at $72^{\circ} \mathrm{C}$. The amplified DNA was analyzed in agarose gel electrophoresis and stained with ethidium bromide. The percentage of agarose in gel was defined according to the molecular weight of the amplicon.

DNA cloning and sequencing. The liberibacter $16 \mathrm{~S}$ rDNA fragment amplified with the OI1 and OI2c primers from HLBsymptomatic plants were purified from the agarose gels using the GTX PCR kit (Amersham Biosciences, Buckinghamshire, UK). The purified insert was cloned into the pGEM-T vector (Promega Corp.) and sequenced using the BigDye Sequencing kit (PE Applied Biosystems, Foster City, $\mathrm{CA})$ in the ABI 3730 automatic sequencer (Applied Biosystems). The DNA fragments were sequenced in both orientations using the T7 (5' TAATACGACTCACTATAGGG 3') and SP6 (5' ATTTAGGTGACACTATAG $3^{\prime}$ ) primers, and 10 clones of each of the 15 cloned inserts were sequenced.

Data analysis. The sequences were assembled using the Seqman software of the LaserGene package (DNASTAR, Madison, WI) and multiple alignment were done in Clustal W (20). Phenetic analysis was performed in Phylip (Phylogeny Inference Package, version 3.6; Joseph Felsentein, Department of Genome Sciences and Department of Biology, University of Washington). The genetic similarity between the samples from the nucleic acid sequences were calculated by the DNADIST program using the Jakes-Cantor model, which assumes that there is independent change at all sites, with equal probability. The phenogram was constructed in the NEIGHBOR software using the unweighted pair group method with arithme-

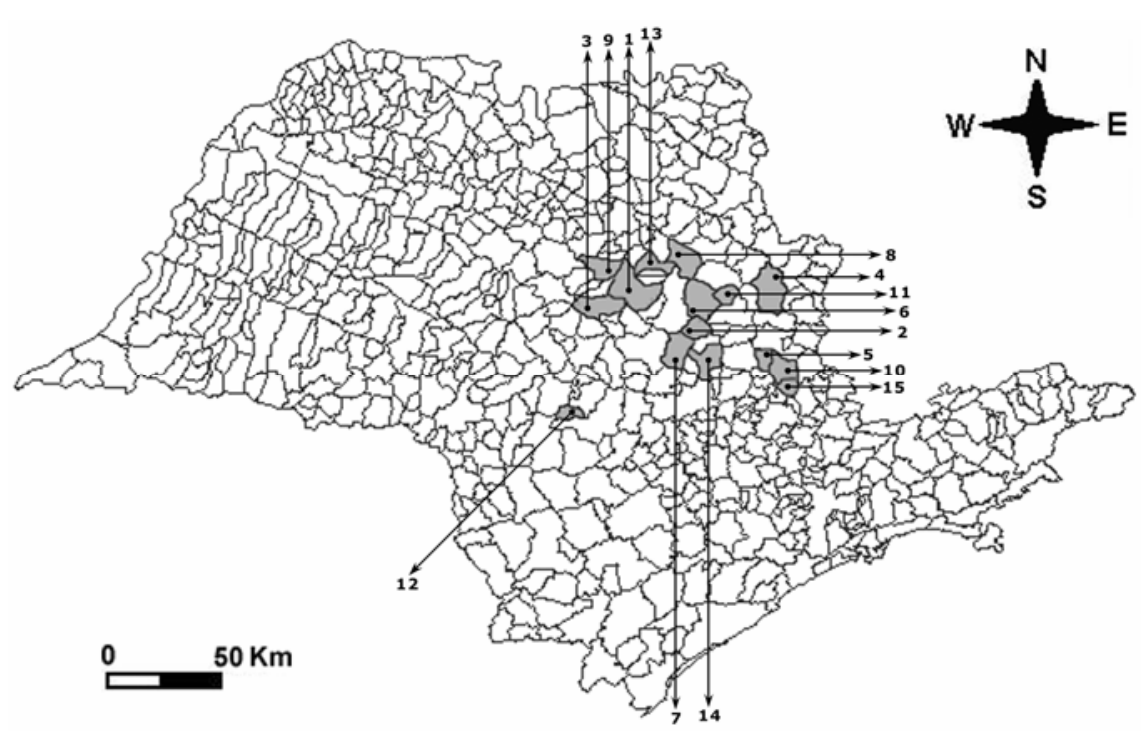

Fig. 1. Map of São Paulo State, Brazil. Marked regions correspond to counties from which huanglongbing-diseased samples were collected and analyzed for the presence of the $\operatorname{LSg} 1$ and $\mathrm{LSg} 2$ forms of Liberibacter. Numbers correspond to the names of the counties listed in Table 2. tic means and the consensus tree was established using the CONSENSE tree program. Bootstraping (1,000 replications) was performed by the SEQBOOT software to estimate the stability and support for the inferred clusters.

\section{RESULTS}

Detection of HLB bacteria in symptomatic plants. In the middle of 2004 , we detected the Asian form of the liberibacter bacteria in 2 of 10 citrus plants with HLB-like symptoms from two orchards located in Araraquara County in the state of São Paulo, Brazil (2). We then started a survey to verify the distribution of the pathogen in orchards and farms that had plants with HLB-like symptoms. Fifty-three HLB-symptomatic plants from different orchards of the state of São Paulo were analyzed (Table 2). Even though the plants displayed classic HLB symptoms, on the first PCR survey using the OI 1 and OI2c primers (12), the bacterium was detected in only 15 of the 53 samples analyzed (28.3\% of the plants) in which an amplified fragment of about $1,200 \mathrm{bp}$ of $16 \mathrm{~S}$ rDNA was generated (Fig. 2; Table 2).

Sequences of $16 \mathrm{~S}$ rDNA from HLB bacteria and the phenogram analysis. Ten clones from each of the $1516 \mathrm{~S}$ rDNA fragments amplified using the OI1/OI2c pair of primers together with template DNA obtained from diseased plants were sequenced in both orientations. The sequences were assembled in SeqMan and generated a 1,124-bp contig corresponding to the expected amplicon. The alignment of all the 150 liberibacter sequences allowed the identification of two distinct groups of sequences, which were designated Liberibacter consensus sequence groups 1 (LSg1) and 2 (LSg2). Of the 150 sequences, 23 belonged to the $\mathrm{LSg} 2$ group and the other 127 corresponded to sequences of LSg1. These $16 \mathrm{~S}$ rDNA liberibacter sequences were compared with the 16S rDNA sequences of other liberibacters available in the GenBank database (Table 3; Fig. 3). The $\operatorname{LSg} 1$ sequences are identical or very similar to the bacteria of the "Ca. L. asiaticus" group (GenBank accession numbers AB008366, AB038369, L22532, and AY192576). The genetic distance from " $\mathrm{Ca}$. L. africanus" (GenBank accession numbers L22533 and AF137368) is a little higher. The other 16S rDNA sequence (LSg2) shows an even

Table 1. Primer sequences used for amplification of different strains of "Candidatus Liberibacter" bacteria from huanglongbing-diseased plants

\begin{tabular}{|c|c|c|c|}
\hline Primers & Nucleotide sequence $\left(5^{\prime}-3^{\prime}\right)$ & $\begin{array}{c}\text { Annealing } \\
\text { temperature }\left({ }^{\circ} \mathrm{C}\right)\end{array}$ & Amplicon size and specificity \\
\hline OI1 & GCGCGTATGCAATACGAGCGGCA & & $1,200 \mathrm{bp}$ for both Asian and African forms \\
\hline $\mathrm{OI} 2 \mathrm{c}$ & GCCTCGCGACTTCGCAACCCAT & 60 & of Candidatus Liberibacter \\
\hline $\mathrm{LSg} 2 \mathrm{f}$ & TTAAGTTAGAGGTGAAATCC & & $545 \mathrm{bp}$ for $\mathrm{LSg} 2$ strain of Candidatus Liberibacter \\
\hline LSg2r & CAACTTAATGATGGCAAATA & 55 & from São Paulo, Brazil \\
\hline $\mathrm{A} 2$ & TATAAAGGTTGACCTTTCGAGTTT & & $703 \mathrm{bp}$ for Asian and $669 \mathrm{bp}$ for African forms \\
\hline J5 & ACAAAAGCAGAAATAGCACGAACAA & 60 & of Candidatus Liberibacter \\
\hline
\end{tabular}


higher genetic distance with the known Asian and African liberibacters.

The presence of two sites of deletion in the nucleotide positions 113 to 126 and 131 to 133,21 transitions, and 10 transversion events plus two point deletions throughout the 1,124 nucleotides were the differences in the 16S rDNA between the HLB-associated organism (LSg2) from São Paulo and LSg1 (Table 4). Despite these differences, the aligned sequences of Liberibacter isolate $\mathrm{LSg} 2$ share 1,064 of 1,122 nucleotides. This similarity observed

for $\mathrm{LSg}$ 2, although not as high as for $\mathrm{LSg} 1$ allow us to classify this new associated HLB organism in the " $\mathrm{Ca}$. Liberibacter" genus.

The phenetic analysis of HLB strains from São Paulo and the other liberibacter sequences present in the GenBank database delineates two distinct subgroups, one formed by the GenBank Asian sequences AB008366, AY192576, AB038369, and L22532 together with the LSg1 sequence from São Paulo, and the other by the African isolates (GenBank accessions L22533

Table 2. Polymerase chain reaction (PCR) amplification results using huanglongbing-symptomatic citrus plants from the state of São Paulo (Brazil) for each of the combination of the primers

\begin{tabular}{lccc}
\hline & & \multicolumn{2}{c}{ No. of samples PCR positive } \\
\cline { 3 - 4 } Location & No. of samples & OI1/OI2c & LSg2r/LSg2f \\
\hline 1. Araraquara $^{\mathrm{a}}$ & 5 & 1 & 4 \\
2. Analândia & 4 & 0 & 4 \\
3. Boa Esperança do Sul $^{\mathrm{a}}$ & 2 & 1 & 1 \\
4. Casa Branca $^{\mathrm{a}}$ & 2 & 1 & 1 \\
5. Conchal $^{\text {6. Descalvado }}$ & 2 & 1 & 1 \\
7. Itirapina & 13 & 1 & 12 \\
8. Luis Antonio & 3 & 1 & 2 \\
9. Matão & 5 & 2 & 3 \\
10. Mogi Mirim & 1 & 0 & 1 \\
11. Porto Ferreira & 2 & 1 & 1 \\
12. Pratânia & 2 & 0 & 2 \\
13. Rincão & 2 & 1 & 1 \\
14. Rio Claro & 6 & 2 & 0 \\
15. Santo Antonio Posse & 2 & 2 & 1 \\
Total & 2 & 1 & 38 \\
\hline
\end{tabular}

${ }^{\mathrm{a}}$ Location where some samples were positive by both set of primers.

${ }^{\mathrm{b}} \mathrm{Six}$ samples were amplified only with the OI1/OI2c pair of primers, whereas nine samples were amplified with both OI1/OI2c and $\mathrm{LSg} 2 \mathrm{f} / \mathrm{LSg} 2 \mathrm{r}$.

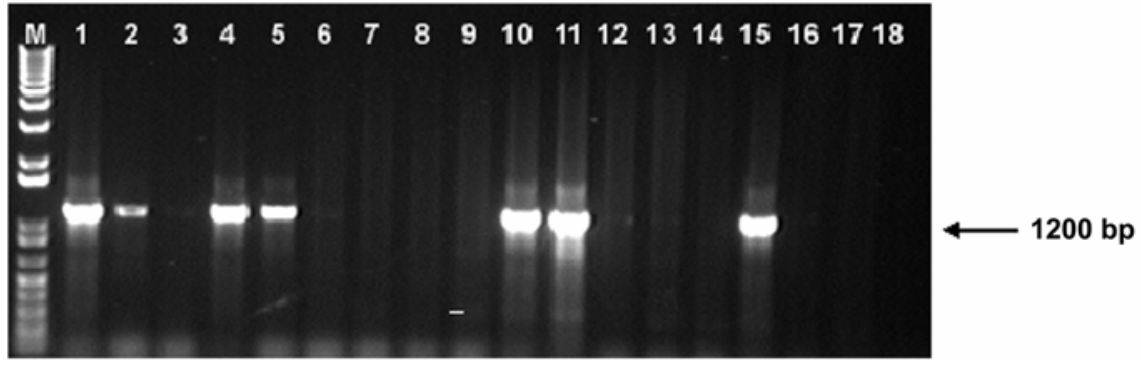

Fig. 2. Agarose gel electrophoresis of the amplicons. Total DNA from the citrus trees was amplified with the OI1/OI2c primers and separated in a $1 \%$ agarose gel. M, molecular marker, 1-kb ladder (Invitrogen); lane 1, positive control (Asian liberibacter); lane 2, positive control (African liberibacter); lane 3 , healthy citrus plant (shot-tip grafted plant); huanglongbing (HLB) symptomatic plants from Rincão (lanes 4 to 9), Luis Antonio (lanes 10 to 14), and Itirapina (lanes 15 to 17); lane 18, HLB symptomless from field. and $\mathrm{AF} 137368)$. The $\mathrm{LSg} 2$ sequence from São Paulo falls in another subgroup-related liberibacter. The clustering obtained in the phenogram was statistically well supported by 1,000 bootstrappings (Fig. 3 ).

Primers designed for PCR amplification of LSg2. The presence of a genetically different sequence associated with HLB organisms and the absence of a good correlation between HLB symptoms and positive PCR using the already known "Ca. Liberibacter" primers OI1 and OI2c led us to design primers for this new HLBassociated organism. The sequence of these primers, named LSg2f and LSg2r, are shown in Table 1 . The primer pairs were expected to generate a 545-bp LSg2specific DNA fragment by PCR.

Assay for primer specificity. DNA extracts from diseased and healthy plants were used as templates of PCR amplification. The amplicons were separated in agarose gels (Fig. 4). The HLB-diseased plants from São Paulo, which previously had resulted in negative PCR using the already described pair of primers for liberibacters, were positive for $\mathrm{LSg} 2 \mathrm{DNA}$ sequences in PCRs using the LSg2f and $\mathrm{LSg} 2 \mathrm{r}$ primers. The molecular weight of the PCR product was in accordance with the expected size. The African and Asian form of HLB, the samples from healthy citrus, as well as some of the samples that were previously amplified with the OI1/OI2c primers (samples 4, 5, 10, 11, and 15) were all negative when using the $\mathrm{LSg} 2 \mathrm{f}$ and LSg2r primers in the same PCR conditions.

PCR amplification of HLB-associated organism in diseased plants. The same 53 samples used for amplification of liberibacter sequences using the pair of primers OI1 and OI2c were used as template of PCR amplifications by the LSg2f and $\mathrm{LSg} 2 \mathrm{r}$ primers. The 38 samples that did not previously amplify with the OI1 and OI2c primers were positive with the $\mathrm{LSg} 2 \mathrm{f}$ and $\mathrm{LSg} 2 \mathrm{r}$ primers. The liberibacter $\mathrm{LSg} 2$ isolate also was amplified in 9 of 15 OI1/OI2c positive samples. The Asian "Ca. Liberibacter" was found alone in only 6 of the 53 samples tested (Table 2). The liberibacters PCR-positive samples were spread across the 15 municipalities sampled (Fig. 1).

Table 3. Matrix genetic distance for 1,124 nucleotides from 16S rDNA isolates of "Candidatus Liberibacter" from São Paulo (LSg1 and LSg2) with the sequences available in the GenBank database ${ }^{\text {a }}$

\begin{tabular}{|c|c|c|c|c|c|c|c|c|}
\hline Huanglongbing organism & 1 & 2 & 3 & 4 & 5 & 6 & 7 & 8 \\
\hline 1. $\mathrm{AB} 038369^{\mathrm{b}}$ & 0000 & $\ldots$ & $\ldots$ & $\ldots$ & $\ldots$ & $\ldots$ & $\ldots$ & $\ldots$ \\
\hline 2. L22532 & 0.004 & 0000 & $\ldots$ & $\ldots$ & $\ldots$ & $\ldots$ & $\ldots$ & $\ldots$ \\
\hline 3. $\operatorname{LSg} 1$ & 0000 & 0.004 & 0000 & $\ldots$ & $\ldots$ & $\cdots$ & $\ldots$ & $\cdots$ \\
\hline 4. $\mathrm{AB} 008366$ & 0000 & 0.001 & 0000 & 0000 & $\ldots$ & $\ldots$ & $\ldots$ & $\ldots$ \\
\hline 5. AY 192576 & 0.002 & 0.006 & 0.002 & 0.002 & 0000 & $\ldots$ & $\ldots$ & $\ldots$ \\
\hline 6. LSg2 & 0.037 & 0.039 & 0.037 & 0.037 & 0.039 & 0000 & $\ldots$ & $\ldots$ \\
\hline 7. L22533 & 0.020 & 0.016 & 0.019 & 0.019 & 0.021 & 0.039 & 0000 & $\ldots$ \\
\hline 8. AF137368 & 0.022 & 0.023 & 0.022 & 0.022 & 0.024 & 0.042 & 0.016 & 0000 \\
\hline
\end{tabular}

a The genetic distances are estimate of the number of nucleotide substitution by site (Jukes and Cantor index).

b GenBank accessions number. 


\section{DISCUSSION}

In the middle of 2004, the Asian form of "Ca. Liberibacter" was detected in citrus plants showing typical HLB symptoms in São Paulo, Brazil (2). Using the set of primers previously described for amplification of the $16 \mathrm{~S}$ rDNA from " $\mathrm{Ca}$. Liberibacter", we have found a low percentage (28\%) of PCR-positive trees displaying classical symptoms of HLB. It has been difficult to detect the HLB bacterium due to its low concentration and uneven distribution in the host $(8,10)$. We observed that the amplification using the OI 1 and OI2c primers resulted in this erratic pattern. When using a second set of primers (A2 and J5; Table 1) which amplify a 703-bp DNA fragment from ribosomal protein gene from the Asian liberibacter (9), the results were the same (data not shown). The quality of DNA also was verified by the successful amplification of all samples with the fD1/rD1 universal $16 \mathrm{~S}$ rDNA primers (21).

The sequences of the 16S rDNA genes are quite conserved among bacteria, but present sufficient variation to design primers for a specific diagnosis of species or strains $(12,22)$. The $16 \mathrm{~S}$ rDNA sequence of the LSg1 Brazilian " $\mathrm{Ca}$. Liberibacter" is identical to sequences of bacteria (GenBank accessions AB038369 and AB008366) identified in Japan from the insect vector and the diseased plants, respectively. The LSg2 Brazilian " $\mathrm{Ca}$. Liberibacter" shows few nucleotide sequence differences from the Asian and African strains, but still shows a high percentage of identical nucleotides (signature sequences). The phenogram based on pairwise comparison of all of those se-

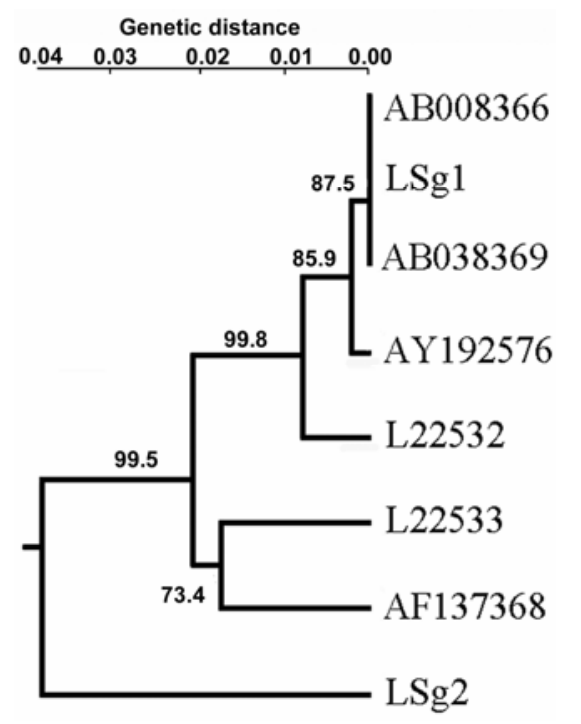

Fig. 3. Phenogram showing the phylogenetic relationships among strains of "Candidatus Liberibacter". The genetic distances were estimated by pairwise comparisons of the $16 \mathrm{~S}$ ribosomal DNA sequences using the Jukes-Cantor parameter. Bootstrap values (based on 1,000 replications) are indicated at the nodes. quences define three clusters, Asian + LSg1, African, and LSg2, characterizing the latter as a new liberibacter strain. Genomic characterization by $16 \mathrm{~S}$ rDNA and serology already had shown differences among the Asiatic and African liberibacters, including the subspecies capensis $(4,11,13)$. Genetic variations among the Asian isolates were observed for the different strains, and they also can be sepa- rated into different groups, those from the Pacific area (Japan, the Philippines, Indonesia, Thailand, and Nepal) and those from India and China (18). Teixeira et al. (19) found a liberibacter variant from HLBdiseased plants in São Paulo, Brazil and, by analysis of the $16 \mathrm{~S}$ rDNA sequences, they designated it as a new species, " $C a$. L. americanus". It is very likely that the $\mathrm{LSg} 2$ isolate and this new " $\mathrm{Ca}$. Liberibacter sp."

Table 4. Nucleotide comparison of $16 \mathrm{~S}$ ribosomal (r)DNA sequence between "Candidatus Liberibacter" strains LSg1 and LSg2 from São Paulo, Brazil

\begin{tabular}{|c|c|c|}
\hline \multirow[b]{2}{*}{ Nucleotide position $^{a}$} & \multicolumn{2}{|c|}{ Liberibacter strain } \\
\hline & LSg1 & LSg2 \\
\hline 4 & A & $\mathrm{C}$ \\
\hline 106 & A & $\mathrm{T}$ \\
\hline $113-126$ & ATCTAGGTAAAAA & - \\
\hline 127 & $\mathrm{C}$ & $\mathrm{T}$ \\
\hline $131-133$ & $\mathrm{ACT}$ & - \\
\hline 143 & $\mathrm{C}$ & A \\
\hline 146 & $\mathrm{G}$ & $\mathrm{T}$ \\
\hline 226 & A & $\mathrm{G}$ \\
\hline 228 & A & G \\
\hline 308 & $\mathrm{C}$ & $\mathrm{T}$ \\
\hline 326 & $\mathrm{~T}$ & $\mathrm{C}$ \\
\hline $328-329$ & TA & $\mathrm{C}-$ \\
\hline 399 & $\mathrm{~T}$ & $\mathrm{C}$ \\
\hline 456 & $\mathrm{G}$ & A \\
\hline 503 & $\mathrm{C}$ & $\mathrm{T}$ \\
\hline 546 & $\mathrm{C}$ & $\mathrm{T}$ \\
\hline 565 & $\mathrm{~T}$ & A \\
\hline 581 & A & $\mathrm{C}$ \\
\hline 595 & A & $\mathrm{G}$ \\
\hline 608 & A & $\mathrm{G}$ \\
\hline 621 & $\mathrm{C}$ & A \\
\hline 652 & $\mathrm{C}$ & $\mathrm{T}$ \\
\hline 689 & G & A \\
\hline $778-779$ & AA & GT \\
\hline 962 & G & A \\
\hline 964 & A & $\mathrm{C}$ \\
\hline $977-978$ & $\mathrm{TC}$ & $\mathrm{CT}$ \\
\hline 985 & $\mathrm{~T}$ & $\mathrm{C}$ \\
\hline 1001 & $\mathrm{C}$ & $\mathrm{T}$ \\
\hline 1007 & A & $\mathrm{G}$ \\
\hline 1010 & $\mathrm{C}$ & $\mathrm{T}$ \\
\hline 1017 & $\mathrm{C}$ & $\mathrm{T}$ \\
\hline 1038 & $\mathrm{C}$ & $\mathrm{T}$ \\
\hline 1040 & A & $\mathrm{T}$ \\
\hline 1042 & $\mathrm{~T}$ & - \\
\hline 1044 & $\mathrm{G}$ & A \\
\hline 1073 & A & $\mathrm{G}$ \\
\hline 1101 & $\mathrm{~T}$ & $\mathrm{C}$ \\
\hline 1104 & $\mathrm{~T}$ & $\mathrm{C}$ \\
\hline
\end{tabular}

a Nucleotide positions are numbered following the sequence of the 16S rDNA of strain LSg1 of "Candidatus Liberibacter asiaticus” from São Paulo, Brazil.

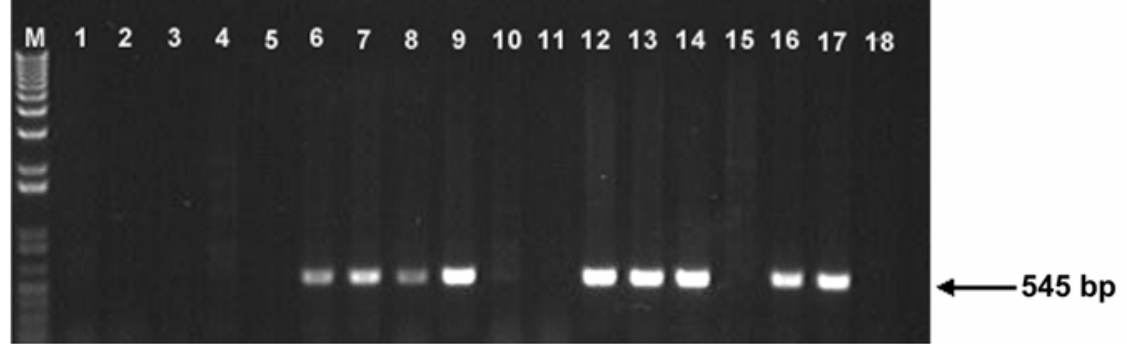

Fig. 4. Agarose gel electrophoresis of the DNA amplified with the LSg2f/LSg2r pair of primers. M, molecular marker, 1-kb ladder (Invitrogen); positive controls of Asian (lane 1) and African Liberibacter (lane 2); healthy plant (lane 3); huanglongbing (HLB) symptomatic plants from Rincão (lanes 4 to 9), Luis Antonio (lanes 10 to 14), and Itirapina (15 to 17); HLB symptomless (lane 18). Samples of the lanes 4, 5, 10, 11, and 15 previously were positive with the OI1/OI2c primers (see Fig. 2). 
are the same Liberibacter strain. Although "Candidatus" has been used for unculturable bacterium lacking definitive classification (15), the species concept for prokaryotes needs much more information than that provided by comparison of $16 \mathrm{~S}$ rDNA sequences only (17).

The LSg2 strain of " $\mathrm{Ca}$. Liberibacter" was predominant throughout the orchards in the state of São Paulo. Interestingly, in nine samples we were able to amplify both sequences, evidencing a mixed infection. All this work was possible because we were able to amplify the fragment of LSg2 strain of " $\mathrm{Ca}$. Liberibacter" using the OI1 and OI2c primers. The frequency of the LSg2 fragment was low compared with LSg1, which could be explained by the variations in the sequence of the region of annealing of primers. Comparing the sequence of $\mathrm{LSg} 2$ variant with the OI1 primer, we observed four mismatches and one insertion, whereas the comparison with OI2c reveals the presence of three mismatches, which could explain the low efficiency of amplification observed when using this combination of primers (data not shown). The probable vector for both bacteria is D. citri, which has been endemic in Brazilian orchards for at least 40 years (3). There is no correlation between the spatial distribution of the focus of the disease and the variants observed in the plants (Table 1; Fig. 1). The pattern observed in the infected plants is always the same, with a predominance of the LSg2 form over LSg1.

The origin of both forms of liberibacter in Brazil is uncertain. Because of the perfect homology between the sequence of the LSg1 strain and strains from Japan, we believe that it probably was introduced in infected material from this Pacific area. The LSg2 strain has never been detected in other parts of the world but it also was identified in another plant species, Murraya paniculata, in Brazil (S. A. Lopes, personal communication). This species also was introduced in Brazil from Asia and the bacterium could have come together with this material. Another possibility is that it was introduced from infected citrus material but, because of the variation in the sequence, it has not been identified previously in the center of origin, Asia and Africa, with the previously available primers. Analysis with the $\mathrm{LSg} 2 \mathrm{r}$ and LSg2f primers needs to be done with plant material from Asia and Africa to verify whether this form is present in these continents. We cannot exclude the possibility that the bacterium came from native plants in Brazil and, with the presence of the vector, was transmitted to citrus, where it was shown to be pathogenic.

In fact, in Brazil we have two different strains of " $\mathrm{Ca}$. Liberibacter" causing severe and almost identical HLB symptoms in citrus trees. By the distribution of the HLB bacteria across São Paulo State orchards that we verified in this work and by the epidemic situation of its possible vector D. citri, an eradication program of HLB-diseased plants needs to be implemented urgently to avoid the rapid spread of the disease.

\section{ACKNOWLEDGMENTS}

We thank the Brazilian growers for providing the samples of the diseased plants. H. D. ColettaFilho, M. A. Machado, and M. L. P. N. Targon are fellowship recipients from $\mathrm{CNPq}$ agency; and $\mathrm{M}$. A. Takita is a fellowship recipient from FAPESP agency.

\section{LITERATURE CITED}

1. Bové, J. M., Calavan, E. C., Capoor, S. P., Cortez, R. E., and Schwarz, R. E. 1974. Influence of temperature on symptoms of California stubborn, South Africa greening, India citrus decline, and Philippines leaf mottling diseases. Pages 12-15 in: Proc. 6th Conf. Int. Organ. Citrus Virol. (IOCV). L. G. Weathers and M. Cohen, eds. University of California, Division of Agricultural Science, Berkeley.

2. Coletta-Filho, H. D., Targon, M. L. P. N., Takita, M. A., de Negri, J. D., Pompeu, J., Jr., do Amaral, A. M., Muller, G. W., and Machado, M. A. 2004. First report of the causal agent of huanglongbing ("Candidatus Liberibacter asiaticus") in Brazil. Plant Dis. 88:1382.

3. Gallo, D., and Montenegro, H. W. S. 1960. Ocorrência de psilideo nos pomares paulistas. Rev. Agric. 35:41-42.

4. Garnier, M., Jagoueix-Eveillard, S., Cronje, P. R., Le Roux, H. F., and Bové, J. M. 2000. Genomic characterization of a liberibacter present in an ornamental rutaceous tree, Calodendrum capense, in the Western Cape Province of South Africa. Proposal of 'Candidatus Liberibacter africanus subsp. capensis'. Int. J. Syst. Evol. Microbiol. 50:2119-2125.

5. Gravena, S., Beretta, M. J. G., Paiva, P. E. B., Gallão, R., and Yamamoto, P. T. 1996. Seasonal abundance and natural enemies of Diaphorina citri (Hemiptera:Psyllidae) in citrus orchards of São Paulo State, Brazil. Page 414 in: Proc. 13th Conf. Int. Organ. Citrus Virol. J. V. da Graça, P. Moreno, and R. K. Yokomi, eds. IOCV, Riverside, CA.

6. Halbert, S. E., and Manjunath, K. L. 2004. Asian citrus psyllids (Sternorryncha:Psyllidae) and greening disease of citrus: a literature review and assessment of risk in Florida. Fla. Entomol. 87:330-353.

7. Halbert, S. E., Niblett, C. L., Manjunath, K. L., Lee, R. F., and Brown, L. G. 2003. Establishment of two new vectors of citrus pathogens in Florida. Pages 1016-1017 in: Proc. Int. Soc. Citricult. Orlando, FL.

8. Harakava, R., Marais, L. J., Ochasan, J., Manjunath, K. L., Febres, V. J., Lee, R. F., and Nib- lett, C. L. 2000. Improved sensitivity in the detection and differentiation of citrus huanglongbing bacteria from South Africa and the Philippines. Pages 195-199 in: Proc. 14th Int. Organ. Citrus Virol. J. V. da Graça, R. F. Lee, and R. K. Yokomi, eds. IOCV, Riverside, CA.

9. Hocquellet, A., Toorawa, P., Bové, J. M., and Garnier, M. 1999. Detection and identification of the two Candidatus Liberobacter species associated with citrus huanglongbing by PCR amplification of ribosomal protein genes of the beta operon. Mol. Cell. Probes 13:373-379.

10. Hung, T. H., Wu, M. L., and Su, H. J. 1999. Development of a rapid method for the diagnosis of citrus greening disease using the polymerase chain reaction. J. Phytopathol. 147:599-604.

11. Jagoueix S., Bové, J. M., and Garnier, M. 1994. The phloem-limited bacterium of greening disease of citrus is a member of the alpha subdivision of the Proteobacteria. Int. J. Syst. Bacteriol. 44:379-386.

12. Jagoueix, S., Bové, J. M., and Garnier, M. 1996. PCR detection of the two 'Candidatus' liberobacter species associated with greening disease of citrus. Mol. Cell. Probes 10:43-50

13. Jagoueix, S., Bové, J. M., and Garnier, M. 1997. Comparison of the $16 \mathrm{~S} / 23 \mathrm{~S}$ ribosomal intergenic regions of "Candidatus Liberobacter asiaticum" and "Candidatus Liberobacter africanum" the two species associated with citrus Huanglongbing (greening) disease. Int. J. Syst. Bacteriol. 47:224-227.

14. Murray, R. E., and Schleifer, K. H. 1994 Taxonomic notes: a proposal for recording the properties of putative taxa of prokaryotes. Int J. Syst. Bacteriol. 44:174-176.

15. Ollive, D. M., and Bean, P. 1999. Principles and applications of methods for DNA-based typing of microbial organisms. J. Clin. Microbiol. 37:1661-1669.

16. Rosseló-Mora, R., and Amann, R. 2001. The species concept for prokaryotes. FEMS Microbiol. Rev. 25:39-67.

17. Subandiyah, S., Iwanami, T., Tsuyumu, S., and Ieki, H. 2000. Comparison of $16 \mathrm{~S}$ rDNA and $16 \mathrm{~S} / 23 \mathrm{~S}$ intergenic region sequences among citrus greening organisms in Asia. Plant Dis. 84:15-18

18. Texeira, D. C., Ayres, J., Kitajima, E. W., Danet, L., Jagoueix-Eveillard, S., Saillard, C., and Bové, J. M. 2005. First report of a Huanglongbing-like disease of Citrus in São Paulo State, Brazil and association of a new Liberibacter species, "Candidatus Liberibacter americanus", with the disease. Plant Dis. 89:107.

19. Thompson, J. D., Higgins, D. G., and Gibson, T. J. 1994. CLUSTAL W: improving the sensitivity of progressive multiple sequence alignment through sequence weighting, positions-specific gap penalties and weight matrix choice. Nucleic Acids Res. 22:4673-4680.

20. Weisburg, W. G., Barns, S. M., Pelletier, D. A. and Lane, D. J. 1991. 16S ribosomal DNA amplification for phylogenetic study. J. Bacteriol. 173:697-703.

21. Zreik, L., Carle, P., Bové, J. M., and Garnier, M. 1995. Characterization of the mycoplasmalike organism associated with the witch's broom disease of the lime and proposition of Candidatus taxon for the organism, Candidatus Phytoplasma aurantifolia. Int. J. Syst. Bacteriol. 45:449-453. 